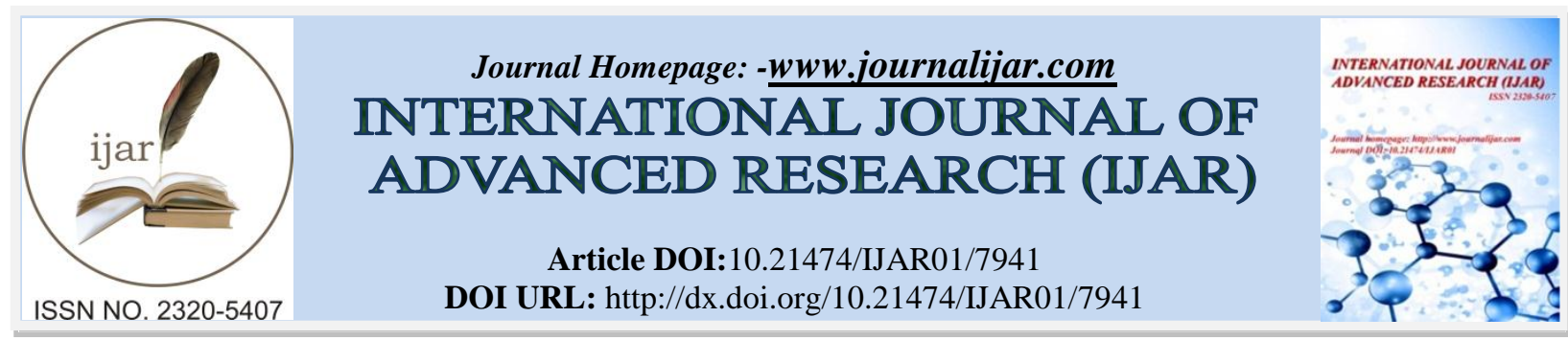

RESEARCH ARTICLE

\title{
COMPARATIVE ANALYSIS OF SOLID WASTE MANAGEMENT IN DEVELOPING SMART CITIES OF INDIA BY AHP: A CASE STUDY.
}

Sukrity Bapat ${ }^{1}$ and R.K.Bhatia ${ }^{2}$.

1. ME, Environmental Engineering, Department Of Civil Engineering, JEC, Jabalpur, MP, India.

2. Associate Professor, Department Of Civil Engineering, JEC, Jabalpur, MP, India.

\section{Manuscript Info}

Manuscript History

Received: 15 August 2018

Final Accepted: 17 September 2018

Published: October 2018

Keywords:-

Smart cities, solid waste management, comparative study.

\begin{abstract}
In developing scenario of India, the concept of smart cities is playing a crucial role. The solid waste management is necessary not only in maintaining the hygienic environment but in reducing the probable health hazards. The current study deals in obtaining weightage of chief ingredient of solid waste management viz. chief criteria like waste collection, transportation, disposal, energy recovery etc. along with their respective sub criteria. Putting these weightage to reference, the data obtained in the survey study from Indore, Jabalpur and Nagpur city will be compared. This study will provide vital results to identify achievements as well as the lacuna in the solid waste management process of the respective cities.
\end{abstract}

Copy Right, IJAR, 2018,. All rights reserved.

\section{Introduction:-}

In the current study, the data regarding the collection, transportation, disposal, energy recovery, financial issues and social awareness was collected from the officials as well as public. With the above given chief criteria and sub criteria of each particular criteria, a result with the help of pairwise comparison, was generated. This result achieved lead the study to build an ideal weightage of each element in the performance index.

AHP that is Analytic Hierarchy Process is a multi-criteria decision making method. AHP derives ratio scales from paired comparisons of criteria and allows for some small inconsistencies in judgments. Inputs can be actual measurements, but also subjective opinions. This method is theoretically sound for weighting and selecting individual indicators. In a hierarchical model of a decision problem, broad overall objectiveis the crown of the structure. The lower levels includes the criteria, sub criteria and also alternatives used for evaluation.

AHP consists of three main principles, including hierarchy frame work, priority analysis and consistency verification. Formulating the decision problem in the form of hierarchy framework is first step of AHP, while top level presents object, and later presents criteria and sub-criteria and alternatives. Once a hierarchy framework is constructed, a pair wise comparison matrix is setup at each levels and compare each other according to Saaty's scale. In this study, use of AHP was constructed considering SWM of cities and the criteria are considered. Mathematically the method is based on the solution of an Eigen value problem. The results of the pair-wise comparisons are arranged in a matrix. The first normalized Eigen vector of the matrix gives the ratio scale (weighting), the largest Eigen value determines the consistency ratio. 
Mathematical Formulation for Identification of Weight of Indicator:-

Table 1:-Main Criteria

\begin{tabular}{|l|l|l|l|l|l|l|}
\hline & $\begin{array}{l}\text { Collection \& } \\
\text { storage }\end{array}$ & transportation & Disposal & $\begin{array}{l}\text { Energy } \\
\text { recovery }\end{array}$ & $\begin{array}{l}\text { Financial } \\
\text { issue }\end{array}$ & Awareness \\
\hline $\begin{array}{l}\text { Collection \& } \\
\text { Storage }\end{array}$ & 1 & 2.2 & 2.5 & 3 & 2.5 & 1.5 \\
\hline Transportation & 0.45 & 1 & 2.4 & 3 & 0.38 & 2 \\
\hline Disposal & 0.4 & 0.42 & 1 & 2 & 0.33 & 1.5 \\
\hline $\begin{array}{l}\text { Energy } \\
\text { recovery }\end{array}$ & 0.333 & 0.33 & 0.5 & 1 & 0.41 & 0.43 \\
\hline Financial issue & 0.4 & 2.6 & 3 & & & \\
\hline Awareness & 0.28 & 0.5 & 0.666 & 2.3 & 0.4 & 1 \\
\hline Total & 2.863 & 7.05 & 10.066 & 13.7 & 5.02 & 8.93 \\
\hline
\end{tabular}

Table 2:-Main Criteria Normalised Matrix

\begin{tabular}{|l|l|l|l|l|l|l|l|l|}
\hline & $\begin{array}{l}\text { Collection } \\
\& \text { storage }\end{array}$ & transportation & Disposal & $\begin{array}{l}\text { Energy } \\
\text { recovery }\end{array}$ & $\begin{array}{l}\text { Financial } \\
\text { issue }\end{array}$ & Awareness & Average & $\%$ \\
\hline $\begin{array}{l}\text { Collection \& } \\
\text { Storage }\end{array}$ & 0.349 & 0.312 & 0.248 & 0.218 & 0.498 & 0.167 & 0.2986 & 29.86 \\
\hline transportation & 0.157 & 0.141 & 0.238 & 0.218 & 0.075 & 0.223 & 0.1753 & 17.53 \\
\hline Disposal & 0.139 & 0.059 & 0.099 & 0.145 & 0.065 & 0.167 & 0.1123 & 11.23 \\
\hline $\begin{array}{l}\text { Energy } \\
\text { recovery }\end{array}$ & 0.116 & 0.046 & 0.049 & 0.072 & 0.081 & 0.048 & 0.0686 & 6.86 \\
\hline Financial issue & 0.139 & 0.368 & 0.298 & 0.175 & 0.199 & 0.279 & 0.2469 & 24.69 \\
\hline Awareness & 0.097 & 0.070 & 0.066 & 0.167 & 0.079 & 0.111 & 0.0983 & 9.83 \\
\hline
\end{tabular}

Sub Criteria:-

Table 3:-Matrix for Collection and Storage

\begin{tabular}{|l|l|l|l|l|l|l|l|}
\hline & Separation & Dumping & Frequency & $\begin{array}{l}\text { Method of } \\
\text { collection }\end{array}$ & Amount & $\begin{array}{l}\text { Convenience } \\
\text { to segregate }\end{array}$ & $\begin{array}{l}\text { Number of } \\
\text { containers }\end{array}$ \\
\hline Separation & 1 & 3.5 & 2.5 & 3 & 4.75 & 3 & 4.25 \\
\hline Dumping & 0.285 & 1 & 0.210 & 0.363 & 0.307 & 0.235 & 0.465 \\
\hline Frequency & 0.4 & 4.75 & 1 & 4.15 & 2.65 & 2.85 & 3.55 \\
\hline $\begin{array}{l}\text { Method of } \\
\text { collection }\end{array}$ & 0.333 & 2.75 & 0.240 & 1 & 0.980 & 3.444 & 0.680 \\
\hline Amount & 0.210 & 3.25 & 0.377 & 1.02 & 1 & 0.2 & 0.350 \\
\hline $\begin{array}{l}\text { Convenience } \\
\text { to segregate }\end{array}$ & 0.333 & 4.25 & $0 . .350$ & 2.25 & 5 & 1 & 3.35 \\
\hline $\begin{array}{l}\text { Number of } \\
\text { containers }\end{array}$ & 0.235 & 2.15 & 0.281 & 1.47 & 2.85 & 0.298 & 1 \\
\hline Total & 2.796 & 21.65 & 4.958 & 13.253 & 17.537 & 8.027 \\
\hline
\end{tabular}

Table 4:-Normalised Matrix for Collection and Storage

\begin{tabular}{|l|l|l|l|l|l|l|l|l|l|}
\hline & $\begin{array}{l}\text { Separat } \\
\text { ion }\end{array}$ & $\begin{array}{l}\text { Dumpin } \\
\mathrm{g}\end{array}$ & $\begin{array}{l}\text { Frequenc } \\
\mathrm{y}\end{array}$ & $\begin{array}{l}\text { Method } \\
\text { of } \\
\text { collectio } \\
\mathrm{n}\end{array}$ & $\begin{array}{l}\text { Amoun } \\
\mathrm{t}\end{array}$ & $\begin{array}{l}\text { Convenien } \\
\text { ce } \\
\text { segregate }\end{array}$ & $\begin{array}{l}\text { Number } \\
\text { of } \\
\text { container } \\
\mathrm{s}\end{array}$ & $\begin{array}{l}\text { Averag } \\
\mathrm{e}\end{array}$ & $\begin{array}{l}\% \\
\text { Separation }\end{array}$ \\
\hline Dumping & 0.357 & 0.161 & 0.504 & 0.226 & 0.270 & 0.373 & 0.311 & 0.314 & 31.4 \\
\hline Frequency & 0.143 & 0.219 & 0.201 & 0.313 & 0.151 & 0.355 & 0.260 & 0.238 & 23.8 \\
\hline $\begin{array}{l}\text { Method of } \\
\text { collection }\end{array}$ & 0.199 & 0.127 & 0.048 & 0.075 & 0.055 & 0.055 & 0.049 & 0.0754 & 7.54 \\
\hline Amount & 0.0751 & 0.150 & 0.076 & 0.076 & 0.057 & 0.024 & 0.025 & 0.069 & 6.9 \\
\hline Convenience & 0.199 & 0.196 & 0.070 & 0.169 & 0.285 & 0.124 & 0.245 & 0.1725 & 17.25 \\
\hline
\end{tabular}




\begin{tabular}{|l|l|l|l|l|l|l|l|l|l|}
\hline to segregate & & & & & & & & & \\
\hline $\begin{array}{l}\text { Number of } \\
\text { containers }\end{array}$ & 0.084 & 0.099 & 0.056 & 0.110 & 0.162 & 0.037 & 0.073 & 0.0887 & 8.87 \\
\hline
\end{tabular}

Table 5:-Matrix for Transportation

\begin{tabular}{|l|l|l|l|}
\hline & Time of collection & $\begin{array}{l}\text { Vehicles used for } \\
\text { collection }\end{array}$ & $\begin{array}{l}\text { Frequency } \\
\text { transportation }\end{array}$ \\
\hline Time of collection for & 0.333 & 3 & 2.5 \\
\hline $\begin{array}{l}\text { Vehicles used of } \\
\text { collection }\end{array}$ & 0.4 & 1 & 0.307 \\
\hline $\begin{array}{l}\text { Frequency } \\
\text { transportation }\end{array}$ & 1.733 & 3.25 & 1 \\
\hline Total & 1 & 7.25 & 3.807 \\
\hline
\end{tabular}

Table 6:-Normalised Matrix for Transportation

\begin{tabular}{|l|l|l|l|l|l|}
\hline & $\begin{array}{l}\text { Time of } \\
\text { collection }\end{array}$ & $\begin{array}{l}\text { Vehicles used } \\
\text { for collection }\end{array}$ & $\begin{array}{l}\text { Frequency of } \\
\text { transportation }\end{array}$ & Average & $\%$ \\
\hline $\begin{array}{l}\text { Time of } \\
\text { collection }\end{array}$ & 0.577 & 0.413 & 0.656 & 0.547 & 54.7 \\
\hline $\begin{array}{l}\text { Vehicles used } \\
\text { for collection }\end{array}$ & 0.192 & 0.137 & 0.080 & 0.136 & 13.6 \\
\hline $\begin{array}{l}\text { Frequency of } \\
\text { transportation }\end{array}$ & 0.230 & 0.448 & 0.262 & 0.317 & 31.7 \\
\hline
\end{tabular}

Table 7:-Matrix for Disposal

\begin{tabular}{|l|l|l|l|l|}
\hline & Landfilling & Incineration & Recycling & $\begin{array}{l}\text { Biological } \\
\text { processing }\end{array}$ \\
\hline Landfilling & 1 & 2.5 & 0.210 & 0.1666 \\
\hline Incineration & 0.4 & 1 & 0.181 & 0.275 \\
\hline Recycling & 4.75 & 5.5 & 1 & 1.5 \\
\hline $\begin{array}{l}\text { Biological } \\
\text { processing }\end{array}$ & 6 & 3.625 & 0.666 & 1 \\
\hline Total & 12.15 & 12.625 & 2.057 & 2.9416 \\
\hline
\end{tabular}

Table 8:-Normalised Matrix for Disposal

\begin{tabular}{|l|l|l|l|l|l|l|}
\hline & Landfilling & Incineration & Recycling & $\begin{array}{l}\text { Biological } \\
\text { processing }\end{array}$ & Average & $\%$ \\
\hline Landfilling & 0.082 & 0.198 & 0.102 & 0.056 & 0.1095 & $10.95 \%$ \\
\hline Incineration & 0.032 & 0.079 & 0.087 & 0.093 & 0.0727 & $7.27 \%$ \\
\hline Recycling & 0.390 & 0.435 & 0.486 & 0.510 & 0.457 & $45.7 \%$ \\
\hline $\begin{array}{l}\text { Biological } \\
\text { processing }\end{array}$ & 0.493 & 0.287 & 0.323 & 0.340 & 0.3608 & $36.08 \%$ \\
\hline
\end{tabular}

Table 9:-Matrix for Energy Recovery

\begin{tabular}{|l|l|l|l|}
\hline & Waste to energy & Efficiency & Segregation of waste \\
\hline Waste to energy & 1 & 1.2 & 0.2 \\
\hline Efficiency & 0.833 & 1 & 0.333 \\
\hline Segregation of waste & 5 & 3 & 1 \\
\hline Total & 6.833 & 5.2 & 1.533 \\
\hline
\end{tabular}

Table 10:-Normalised Matrix for Energy Recovery

\begin{tabular}{|l|l|l|l|l|l|}
\hline & Waste to energy & Efficiency & Segregation of waste & Average & $\%$ \\
\hline Waste to energy & 0.146 & 0.230 & 0.130 & 0.168 & 16.80 \\
\hline Efficiency & 0.121 & 0.192 & 0.217 & 0.176 & 17.60 \\
\hline
\end{tabular}




\begin{tabular}{|l|l|l|l|l|l|}
\hline Segregation of waste & 0.731 & 0.576 & 0.652 & 0.656 & 65.60 \\
\hline
\end{tabular}

Table 11:-Matrix for Financial Issue

\begin{tabular}{|l|l|l|l|l|l|l|l|l|}
\hline & $\begin{array}{l}\text { Safety } \\
\text { measure }\end{array}$ & $\begin{array}{l}\text { monthly } \\
\text { expenditure }\end{array}$ & Fine & Tax & $\begin{array}{l}\text { Man } \\
\text { power }\end{array}$ & Profit & $\begin{array}{l}\text { Waste } \\
\text { cultivation }\end{array}$ & $\begin{array}{l}\text { Workers } \\
\text { salary }\end{array}$ \\
\hline $\begin{array}{l}\text { Safety } \\
\text { measure }\end{array}$ & 1 & 4.5 & 3 & 3 & 2.5 & 2.85 & 3.5 & 2.65 \\
\hline $\begin{array}{l}\text { monthly } \\
\text { expenditure }\end{array}$ & 0.222 & 1 & 3 & 2.64 & 1.85 & 1.75 & 3.8 & 1.2 \\
\hline Fine & 0.333 & 0.333 & 1 & 2.75 & 2.64 & 1.25 & 0.222 & 0.666 \\
\hline Tax & 0.333 & 0.378 & 0.363 & 1 & 0.333 & 1.2 & 0.222 & 2.5 \\
\hline Man power & 0.4 & 0.540 & 0.378 & 3 & 1 & 2.5 & 0.4 & 1.25 \\
\hline Profit & 0.350 & 0.571 & 0.8 & 0.833 & 0.4 & 1 & 0.333 & 0.952 \\
\hline $\begin{array}{l}\text { Waste } \\
\text { cultivation }\end{array}$ & 0.285 & 0.263 & 4.5 & 4.5 & 2.5 & 3 & 1 & 3 \\
\hline $\begin{array}{l}\text { Workers } \\
\text { salary }\end{array}$ & 0.377 & 0.833 & 1.5 & 0.4 & 0.8 & 1.05 & 0333 & 1 \\
\hline total & 3.3 & 8.418 & 14.541 & 18.123 & 12.023 & 14.6 & 9.81 & 13.218 \\
\hline
\end{tabular}

Table12:-Normalised Matrix for Financial Issue

\begin{tabular}{|l|l|l|l|l|l|l|l|l|l|l|}
\hline & $\begin{array}{l}\text { Safety } \\
\text { measure }\end{array}$ & $\begin{array}{l}\text { monthly } \\
\text { expenditure }\end{array}$ & Fine & Tax & $\begin{array}{l}\text { Man } \\
\text { power }\end{array}$ & Profit & $\begin{array}{l}\text { Waste } \\
\text { cultivation }\end{array}$ & $\begin{array}{l}\text { Workers } \\
\text { salary }\end{array}$ & Average & $\%$ \\
\hline $\begin{array}{l}\text { Safety } \\
\text { measure }\end{array}$ & 0.303 & 0.534 & 0.206 & 0.165 & 0.207 & 0.195 & 0.356 & 0.200 & 0.2707 & 27.07 \\
\hline $\begin{array}{l}\text { monthly } \\
\text { expenditure }\end{array}$ & 0.067 & 0.118 & 0.206 & 0.145 & 0.153 & 0.119 & 0.387 & 0.090 & 0.1606 & 16.06 \\
\hline Fine & 0.100 & 0.0395 & 0.068 & 0.151 & 0.219 & 0.085 & 0.022 & 0.050 & 0.0917 & 9.67 \\
\hline Tax & 0.100 & 0.044 & 0.024 & 0.055 & 0.027 & 0.082 & 0.022 & 0.189 & 0.0678 & 6.78 \\
\hline Man power & 0.121 & 0.064 & 0.025 & 0.165 & 0.083 & 0.171 & $0 . .040$ & 0.094 & 0.0953 & 9.53 \\
\hline Profit & 0.106 & 0.067 & 0.055 & 0.045 & 0.033 & 0.068 & 0.033 & 0.072 & 0.0598 & 5.98 \\
\hline $\begin{array}{l}\text { Waste } \\
\text { cultivation }\end{array}$ & 0.086 & 0.031 & 0.309 & 0.248 & 0.207 & 0.205 & 0.101 & 0.226 & 0.1760 & 17.64 \\
\hline $\begin{array}{l}\text { Workers } \\
\text { salary }\end{array}$ & 0.114 & 0.098 & 0.103 & 0.022 & 0.066 & 0.071 & 0.033 & 0.075 & 0.0727 & 7.27 \\
\hline
\end{tabular}

Table 13:-Matrix for Awarness

\begin{tabular}{|l|l|l|l|l|}
\hline & Campaign & Mobile application & Adverting promotion & Complaints \\
\hline Campaign & 1 & 4.5 & 0.380 & 3.75 \\
\hline Mobile application & 0.222 & 1 & 0.258 & 1.25 \\
\hline Adverting promotion & 2.625 & 3.875 & 1 & 2.75 \\
\hline Complaints & 0.266 & 0.8 & 0.347 & 1 \\
\hline & 4.11 & 10.17 & 1.98 & 8.75 \\
\hline
\end{tabular}

Table 14:-Normalised Matrix for Awareness

\begin{tabular}{|l|l|l|l|l|l|l|}
\hline & Campaign & $\begin{array}{l}\text { Mobile } \\
\text { application }\end{array}$ & $\begin{array}{l}\text { Adverting } \\
\text { promotion }\end{array}$ & Complaints & Average & $\%$ \\
\hline Campaign & 0.243 & 0.442 & 0.191 & 0.428 & 0.3269 & $32.69 \%$ \\
\hline $\begin{array}{l}\text { Mobile } \\
\text { application }\end{array}$ & 0.053 & 0.098 & 0.129 & 0.142 & 0.1056 & $10.56 \%$ \\
\hline $\begin{array}{l}\text { Adverting } \\
\text { promotion }\end{array}$ & 0.638 & 0.380 & 0.503 & 0.314 & 0.4599 & $45.99 \%$ \\
\hline Complaints & 0.064 & 0.0786 & 0.174 & 0.114 & 0.1076 & $10.76 \%$ \\
\hline
\end{tabular}




\section{Check for the consistency:-}

Calculate largest Eigen value $\delta=\mathrm{S}_{\mathrm{c} 1} \mathrm{X}_{1}+\mathrm{S}_{\mathrm{c} 2} \mathrm{X}_{2}+\mathrm{S}_{\mathrm{c} 3} \mathrm{X}_{3}+\mathrm{S}_{\mathrm{c} 4} \mathrm{X}_{4}+\mathrm{S}_{\mathrm{c} 5} \mathrm{X}_{5}+\mathrm{S}_{\mathrm{c} 6} \mathrm{X}_{6}$

Calculate consistency index $(\mathrm{CI})$,

$\mathrm{CI}=\frac{\delta-n}{n-1}$

Verify consistency ratio $(\mathrm{CR})<10 \%$

$\mathrm{CR}=\frac{C I}{R I}$

\begin{tabular}{|c|c|c|c|c|c|c|c|c|c|c|c|c|c|c|c|}
\hline \multicolumn{10}{|c|}{ Order of the matrix } \\
\hline $\begin{array}{c}\text { Matrix order } \\
\text { no. }\end{array}$ & 1 & 2 & 3 & 4 & 5 & 6 & 7 & 8 & 9 & 10 & 11 & 12 & 13 & 14 & 15 \\
\hline RI value & 0.0 & 0.0 & 0.58 & 0.90 & 1.12 & 1.24 & 1.32 & 1.41 & 1.45 & 1.49 & 1.51 & 1.54 & 1.56 & 1.57 & 1.59 \\
\hline
\end{tabular}

Figure 1:-Random Index RI (The Consistency Indices of Randomly Generated Reciprocal Matrices)

Referring the equations above, largest Eigen value $\delta$, consistency index and consistency ratio can be calculated. Each criteria, sub criteria and weights are calculated and checked for consistency. Value of consistency ratio should be less than 0.1 at all levels then and only then the judgements are granted correct.

Weight of sub criteria in each set is multiplied by weight of main criteria of its own criteria to determine its weight in whole system.

Calculations of the main criteria to verify the judgements by consistency ratio:$\delta=(2.863 \times 0.29)+(7.05 \times 0.175)+(10.06 \times 0.11)+(13.7 \times 0.068)+(5.02 \times 0.24)+(8.93 \times 0.098)$

Total $\delta=6.3034$

$\mathrm{CI}=\frac{0.3034-6}{6-1}=\frac{0.3034}{5}=0.060$

$\mathrm{CR}=\frac{0.060}{1.24}=0.0489<0.1$

Calculation of every sub criteria was calculated as per the process explained above for the main criteria.The CR value of each of the sub criteria came out to be less than 0.1 which proves the judgements correct.

\section{Comparative analysis of SWM of Jabalpur, Indore and Nagpur cities of India:-}

Jabalpur city is located in Jabalpurdistrict of Madhya Pradesh state, on the right Bank of Narmada River. Jabalpur city lies at having coordinates $79^{\circ} 55^{\prime} 37^{\prime \prime}$ to $79^{\circ} 57^{\prime} 54^{\prime}$ ' longitudes and $23^{\circ} 09^{\prime} 10^{\prime \prime}$ to $23^{\circ} 11^{\prime}$ ' $06^{\prime \prime}$ latitudes. Jabalpur is among the major cities of Madhya Pradesh. The population sum ups up to 1,055,525, and decadal growth rate of $14.51 \%$ (according to the 2011 census). The growth of urban population in large Indian cities is leading to pressure of municipal bodies for effective services, SWM being one of the foremost challenges confronting the municipal bodies.Local households, markets, commercial establishments, hotels, restaurants, and hospitals serve as the primary source for production of solid waste. The total quantity of waste generated per day is in the order of 516 tons at the rate of $432 \mathrm{gpcd}$. In the absence of significant tourism-related activity, there is no significant seasonal variation in the quantity of waste generated.

Nagpur is the 13th largest Indian city in terms of population. It has been proposed as one of the Smart Cities in Maharashtra. Nagpur lies at having coordinates $21.15 \mathrm{~N}$ 79.09E . The city covers an area under NMC limit of 227.36 Sq.km and population of the city as per the 2011 census is $23,98,165$. The city is divided into 38 wards. The Nagpur Mahanagar Corporation gave contract to private companies that will work on the project 'electricity from the waste'. Currently, Bhandewadi area dumping ground is used for the collection of the waste. The project was signed by the NMC back in 2017 which will last for next 15years including 2 years of construction. NMC donated around 248 Crores for the project. From this project around 11.5 MW electricity will be produced which will be sold at 7 Rs/unit.

Indore is the most populous and the largest city in the Indian state of Madhya Pradesh. It comes under Tier 2 cities in India. Indore lies at having Coordinates $22^{\circ} 43^{\prime} 0^{\prime \prime} \mathrm{N} 75^{\circ} 50^{\prime} 50^{\prime \prime} \mathrm{E}$ covering area $530 \mathrm{sq}$. km. It has been ranked first in Swachh Bharat Abhiyan two years in a row $(2017$ and 2018) and is thecleanest city in India. The city generates nearly 50,000 kilos of municipal waste every day, 13,000 kilos of which is plastic waste. Plastic is nonbiodegradable and much of it is difficult to recycle. The city used to dispose its daily plastic waste, all 13,000 kilos of it, by burning it. Just five months ago, the city was almost choking in smog caused due to the burning of such 
large amounts of plastic. This is when the Indore Municipal Corporation (IMC) decided to change its strategy and overturn the despicable state of Indore's plastic waste. In January this year they set up a Plastic Collection Centre (PCC) to reuse and recycle the city's plastic waste.

This paper presents the results of a subsequent comparative analysis of the 3 cities, using the fresh and existing data collected to compare and contrast solid waste management systems. This is important tocompare performance of cities and to allow cities to learn from each other. Comparative analysis of solid waste management system of Jabalpur, Indore and Nagpur is carried and results are given in below tables.

\section{Collection \& storage:-}

Main criteria collection \& storage covers separation of SW, dumping of SW, frequency of collection at house hold and further level, type of collection i.e. By hand cart, truck or other vehicle, segregation at different levels, amount of waste, type of waste collected from city. The score of criteria collection \& storage given in table 15 .

It is observed from the score of collection and storage that Indore leads in the first place because it scored 258.55 that is $87 \%$ of the weightage. Indore has a better system for collection and segregation of waste and $100 \%$ frequency of waste collection. Every day door to door collection twice a day increase awareness in public. Jabalpur has door to door collection but it reached only 60-70\%. Jabalpur and Nagpur needs to improvise in terms of collection and segregation of waste.

Table15:- Score of Main Criteria Collection \& Storage

\begin{tabular}{|l|l|l|l|l|l|}
\hline Code & Collection \& storage & $\begin{array}{l}\text { Weight of sub } \\
\text { criteria }\end{array}$ & $\begin{array}{l}\text { Score } \\
\text { Jabalpur }\end{array}$ & Score of Indore & $\begin{array}{l}\text { Score } \\
\text { Nagpur }\end{array}$ \\
\hline $\mathbf{0 1}$ & Separation & $\mathbf{9 3 . 7 6}$ & 75.00 & $\mathbf{8 1 . 6 1}$ & 66.97 \\
\hline $\mathbf{0 2}$ & Dumping & $\mathbf{1 2 . 6 6}$ & $\mathbf{7 . 5 9}$ & $\mathbf{1 0 . 5 2}$ & $\mathbf{5 . 5 4}$ \\
\hline $\mathbf{0 3}$ & Frequency & $\mathbf{7 1 . 0 6}$ & $\mathbf{4 2 . 6 3}$ & $\mathbf{7 0 . 3 6}$ & 29.77 \\
\hline $\mathbf{0 4}$ & Method of collection & $\mathbf{2 2 . 5}$ & $\mathbf{1 4 . 3 5}$ & $\mathbf{1 9 . 8 5}$ & $\mathbf{1 0 . 2 8}$ \\
\hline $\mathbf{0 5}$ & Amount & $\mathbf{2 0 . 6 9}$ & $\mathbf{9 . 7 2}$ & $\mathbf{1 8 . 4 6}$ & $\mathbf{8 . 4 3}$ \\
\hline $\mathbf{0 6}$ & $\begin{array}{l}\text { Convenience } \\
\text { segregate }\end{array}$ & $\mathbf{5 1 . 5 0 8}$ & $\mathbf{3 1 . 7 8}$ & $\mathbf{4 4 . 9 1}$ & $\mathbf{2 3 . 0 5}$ \\
\hline $\mathbf{0 7}$ & Number of containers & $\mathbf{2 6 . 4 8}$ & $\mathbf{1 7 . 5 7}$ & $\mathbf{2 2 . 8 4}$ & $\mathbf{1 4 . 6 2}$ \\
\hline & $\mathbf{2 9 8 . 5 9}$ & $\mathbf{1 9 8 . 6 4}$ & $\mathbf{2 5 8 . 5 5}$ & $\mathbf{1 5 8 . 6 6}$ \\
\hline
\end{tabular}

\section{Transportation:-}

Main criteria transportation covers type of vehicle used for system, time of collection and frequency of transport of solid waste from city. Score of criteria transportation given in table 16. Indore has a better transportation system of waste management. It achieves about 96 percentile of the actual weightage. Indore have 800 vehicles with live tracking by GPS system. They collect garbage twice a day from every area of city. The city also segregated compartments for wet and dry waste, for bio medical waste different cart run all over the city.

Jabalpur has 60 around vehiclesand 400 hand cart for collection of waste from different parts of the city. Door to door collection done ones a day that it achieves $63 \%$ of actual weightage and Nagpur $43 \%$.

Table16:-Score of Main Criteria Transportation

\begin{tabular}{|c|c|c|c|c|c|}
\hline Code & transportation & $\begin{array}{l}\text { Weight of sub } \\
\text { criteria }\end{array}$ & $\begin{array}{l}\text { Score } \\
\text { Jabalpur }\end{array}$ & Score of Indore & $\begin{array}{l}\text { Score } \\
\text { Nagpur }\end{array}$ \\
\hline 08 & Time of collection & 95.88 & 57.52 & 87.70 & 40.17 \\
\hline 09 & $\begin{array}{l}\text { Vehicles used for } \\
\text { collection }\end{array}$ & 23.84 & 19.07 & 23.84 & 12.87 \\
\hline \multirow[t]{2}{*}{10} & $\begin{array}{ll}\begin{array}{l}\text { Frequency } \\
\text { transportation }\end{array} & \text { of }\end{array}$ & 55.57 & 33.34 & 55.57 & 22.22 \\
\hline & & 175.29 & 109.93 & 167.11 & 75.26 \\
\hline
\end{tabular}




\section{Disposal:-}

In the process of solid waste management, there are different ways of disposal i.e. landfilling, incineration, recycling and biological processing can be implemented depending upon the material. In incineration processing Jabalpur have a $100 \%$ score as the incineration plant is in fully working state. Along with incineration, biological processing is also implemented but due to lack of segregation of waste, larger portion of waste which is biologically treated is sent for the incineration plant.

In Indore they have Asia's biggest bio-methanisation plant which treatsaround 20 tons of organic waste daily, so in biological processing it scores $100 \%$.From being labelled as the biggest plastic waste generator in Madhya Pradesh in 2013 , to putting $50 \%$ of city's plastic waste to reuse in 2017 , Indore is a shining example to other big cities in India batteling with waste management woes. Nagpur show poor performance in this criteria it does not have any proper solid waste management plant and not any recycling done at government level. Score of criteria Disposal given in table 17.

Table 17:-Score of Main Criteria Disposal

\begin{tabular}{|l|l|l|l|l|l|}
\hline Code & Disposal & $\begin{array}{l}\text { Weight of sub } \\
\text { criteria }\end{array}$ & $\begin{array}{l}\text { Score of } \\
\text { Jabalpur }\end{array}$ & Score of Indore & $\begin{array}{l}\text { Score } \\
\text { Nagpur }\end{array}$ \\
\hline 11 & Landfilling & $\mathbf{1 2 . 2 9}$ & $\mathbf{1 2 . 2 9}$ & $\mathbf{1 2 . 2 9}$ & 7.37 \\
\hline 12 & Incineration & $\mathbf{8 . 1 6 4}$ & $\mathbf{8 . 1 6 4}$ & 6.53 & 3.26 \\
\hline 13 & Recycling & $\mathbf{5 1 . 4 2 2}$ & $\mathbf{2 5 . 6 6}$ & $\mathbf{4 5 . 1 6}$ & $\mathbf{3 0 . 7 9}$ \\
\hline 14 & Biological processing & $\mathbf{4 0 . 5 1 7}$ & $\mathbf{2 4 . 3 1}$ & $\mathbf{4 0 . 5 1 7}$ & $\mathbf{1 6 . 2 0}$ \\
\hline & & 112.2392 & $\mathbf{7 0 . 4 2}$ & $\mathbf{1 0 4 . 4 9}$ & $\mathbf{5 7 . 6 2}$ \\
\hline
\end{tabular}

\section{Energy recovery:-}

Waste to energy (WTE) is a term that is used to describe various technologies that convert non-recyclable waste into usable forms of energy including heat, fuels and electricity. WTE can occur through a number of processes such as incineration, gasification, pyrolysis, anaerobic digestion, and landfill gas recovery. Here, the term WTE is commonly used in specific reference to incineration which burns completely combusted waste at ultra-high temperatures allowing for energy recovery. Inthis, Indore and Jabalpur both have nearbyequivalent percentage.

Jabalpur hadwaste to energy plant kathonda, which converts waste of all over city into useful energy (electricity, ash, fuel gases) but efficiency of plant effected if waste is not segregated properly because wet waste have more energy to burn which reduces the efficiency of plant so that wet waste is not properly sent to composting sites.

Indore have their bio- methanation plant but waste to energy plant is not present currently.

Nagpur hasits own energy recovery project 'electricity from the waste'. The project was signed by the NMC back in 2017 which will last for next 15years including 2 years of construction. It is still not completed. Score of criteria Energy recovery given in table 18 .

Table 18:-Score of Main Criteria Energy Recovery

\begin{tabular}{|l|l|l|l|l|l|}
\hline Code & Energy recovery & Weight of sub criteria & Score of Jabalpur & Score of Indore & Score of Nagpur \\
\hline 15 & Waste to energy & $\mathbf{1 1 . 5 2 4}$ & $\mathbf{9 . 6 8}$ & $\mathbf{8 . 2 9}$ & $\mathbf{4 . 6 0}$ \\
\hline 16 & Efficiency & $\mathbf{1 2 . 0 7 3}$ & $\mathbf{9 . 6 5}$ & $\mathbf{6 . 0 3}$ & $\mathbf{2 . 4 1}$ \\
\hline 17 & Segregation of waste & $\mathbf{4 5}$ & $\mathbf{3 1 . 5}$ & $\mathbf{4 1 . 4}$ & $\mathbf{1 8}$ \\
\hline & & $\mathbf{6 8 . 5 9}$ & $\mathbf{5 0 . 8 3}$ & $\mathbf{5 5 . 7 5}$ & $\mathbf{2 5 . 0 1}$ \\
\hline
\end{tabular}

\section{Financial issue:-}

This includes safety measures for workers; whole monthly expenditure for waste collection, transportation, disposal, energy recovery and also workers salary; fine for not following direction and tax for management from public; no of workers and vehicles; profit from energy recovery plant, recycling plant etc.

In financial evaluation Indore scored $90 \%$ as it recycles $50 \%$ of plastic. Indore generates compost out of biological waste. This city municipal corporation has also set particular charges in terms of finefor splitting on the public 
property, not using dustbins etc. Such strict terms also play an important role in cleaning city and creating awareness. Spot fine collection has been roughly noted to around 80lacs in last 18 months in Indore. Indore have 800 vehicles with live tracking by GPS system. 2200 twin bins installed in 92 commercial areas. Total number of staff is 6500 at present. Estimated amount spent on the drive was 60crore.

In Jabalpur total number of staff is 3200 at present. Estimated spent amount for waste management plant is 1470 rupee per ton. Waste generation per day around is $520+/-10 \%$ TPD which is likely to reach at around 600 TPD by 2020. At present plant is working with the capacity of 580 TPD which shows that it only meets present demand and cannot process the dumped waste. This year plant runs on 90\% PLF and efficiency at net calorific value 1650 $\mathrm{Kcal} / \mathrm{Kg}$. Score of criteria financial issue is given in table 19.

Table 19:-Score of Main Criteria Financial Issue

\begin{tabular}{|l|l|l|l|l|l|}
\hline Code & Financial & $\begin{array}{l}\text { Weight of sub } \\
\text { criteria }\end{array}$ & $\begin{array}{l}\text { Score } \\
\text { Jabalpur }\end{array}$ & of & $\begin{array}{l}\text { Score of Indore } \\
\text { Nagpur }\end{array}$ \\
\hline 18 & Safety measure & $\mathbf{6 6 . 8 3}$ & 40.09 & $\mathbf{5 3 . 5 4}$ & $\mathbf{3 3 . 4 1}$ \\
\hline 19 & monthly expenditure & $\mathbf{3 9 . 6 5 2}$ & $\mathbf{3 5 . 6 8}$ & $\mathbf{3 5 . 6 8}$ & $\mathbf{2 3 . 7 9}$ \\
\hline 20 & Fine & $\mathbf{2 3 . 8 7}$ & $\mathbf{9 . 5 4}$ & $\mathbf{2 3 . 8 7}$ & 4.77 \\
\hline 21 & Tax & $\mathbf{1 6 . 7 3}$ & $\mathbf{1 6 . 7 3}$ & $\mathbf{1 6 . 7 3}$ & $\mathbf{1 6 . 7 3}$ \\
\hline $\mathbf{2 2}$ & Man power & $\mathbf{2 3 . 5 2}$ & $\mathbf{1 8 . 8 1}$ & $\mathbf{2 3 . 5 2}$ & $\mathbf{1 4 . 1 1}$ \\
\hline $\mathbf{2 3}$ & Profit & $\mathbf{1 4 . 7 6}$ & $\mathbf{1 0 . 3 3}$ & $\mathbf{1 1 . 8 0}$ & $\mathbf{7 . 3 8}$ \\
\hline $\mathbf{2 4}$ & Waste cultivation & $\mathbf{4 3 . 5 5}$ & $\mathbf{3 3 . 0 9}$ & $\mathbf{4 1 . 8 0}$ & $\mathbf{2 1 . 7 7}$ \\
\hline 25 & Workers salary & $\mathbf{1 7 . 9 4}$ & $\mathbf{1 4 . 3 5}$ & $\mathbf{1 6 . 1 4}$ & $\mathbf{1 2 . 5 5}$ \\
\hline & TOTAL & $\mathbf{2 4 6 . 8 5}$ & $\mathbf{1 7 8 . 6 2}$ & $\mathbf{2 2 3 . 0 8}$ & $\mathbf{1 3 4 . 5 1}$ \\
\hline
\end{tabular}

\section{Awareness:-}

Awareness is very important because public support and is must for proper regulation of solid waste management in cities. This includes campaigns, adverting promotion, and use of mobile applications to achieve the goal of clean cities. How local government react on complaints also encourages public.

Indore has the best performance among other cities. In Indore 6 NGOs including BASIX with 400 volunteers have been roped in to explain sorting, segregation and to create public awareness. A huge awareness campaign was launched across media likeradio FM, TV advertisements, jingles, talk shows and newspapers. Slogans have been painted on one \& half lakh square metre of wall space across city. 1, 27,012 swachhta app "Help line 311" downloaded in Indore and from 37,486 complaints 35,548 complaints had been resolved within 24 hours (94.83\%).

In Jabalpur slogans have been painted and in some area goal of clean city had been achieved though it is not fulfilled by every area of city.Some parts of city are still unaware ofthe scheme. Mobile application was launched in Jabalpur nagar nigam but due to lack of mobile application users very few complaints had been received.

Nagpur had poor performance in this criterion. Nagpur lacksadvertising, mobile application and even few wall slogans wereobservedonly in the civil areas. Score of criteria Awareness given in table 20.

Table 20:-Score of Main Criteria Awareness

\begin{tabular}{|l|l|l|l|l|l|}
\hline Code & Awareness & $\begin{array}{l}\text { Weight of sub } \\
\text { criteria }\end{array}$ & $\begin{array}{l}\text { Score of } \\
\text { Jabalpur }\end{array}$ & Score of Indore & $\begin{array}{l}\text { Score } \\
\text { Nagpur }\end{array}$ \\
\hline 26 & Campaign & 32.13 & 25.70 & 32.13 & 12.85 \\
\hline 27 & $\begin{array}{l}\text { Mobile } \\
\text { application }\end{array}$ & 10.380 & 7.26 & 9.34 & 2.07 \\
\hline 28 & $\begin{array}{l}\text { Adverting } \\
\text { promotion }\end{array}$ & 45.208 & 36.16 & 45.208 & 18.06 \\
\hline 29 & Complaints & 10.57 & 6.34 & 9.93 & 2.11 \\
\hline & & 98.288 & 75.46 & 96.60 & 35.09 \\
\hline
\end{tabular}


Table 21:-Final Score Showing the Performance of Jabalpur, Indore and Nagpur

\begin{tabular}{|l|l|l|l|l|}
\hline Main criteria & $\begin{array}{l}\text { Weight of main } \\
\text { criteria }\end{array}$ & $\begin{array}{l}\text { Final Score of } \\
\text { Jabalpur }\end{array}$ & $\begin{array}{l}\text { Final Score of } \\
\text { Indore }\end{array}$ & $\begin{array}{l}\text { Final Score of } \\
\text { Nagpur }\end{array}$ \\
\hline Collection \& storage & 298.59 & $198.64(66.52 \%)$ & $258.55(86.59 \%)$ & $158.66(53.31 \%)$ \\
\hline Transportation & 175.29 & $109.93(62.71 \%)$ & $167.11(95.33 \%)$ & $75.26(42.93 \%)$ \\
\hline Disposal & 112.392 & $70.42(62.65 \%)$ & $104.49(92.96 \%)$ & $57.62(51.26 \%)$ \\
\hline Energy recovery & 68.59 & $50.83(74.10 \%)$ & $55.75(81.28 \%)$ & $25.01(36.46 \%)$ \\
\hline Financial issue & 246.85 & $178.62(72.35 \%)$ & $223.08(90.37 \%)$ & $134.51(54.49 \%)$ \\
\hline Awareness & 98.288 & $75.46(76.77 \%)$ & $96.60(98.28 \%)$ & $35.09(35.70 \%)$ \\
\hline Total & 1000.0 & $683.9(68.39 \%)$ & $905.58(90.55 \%)$ & $486.15(48.61 \%)$ \\
\hline
\end{tabular}

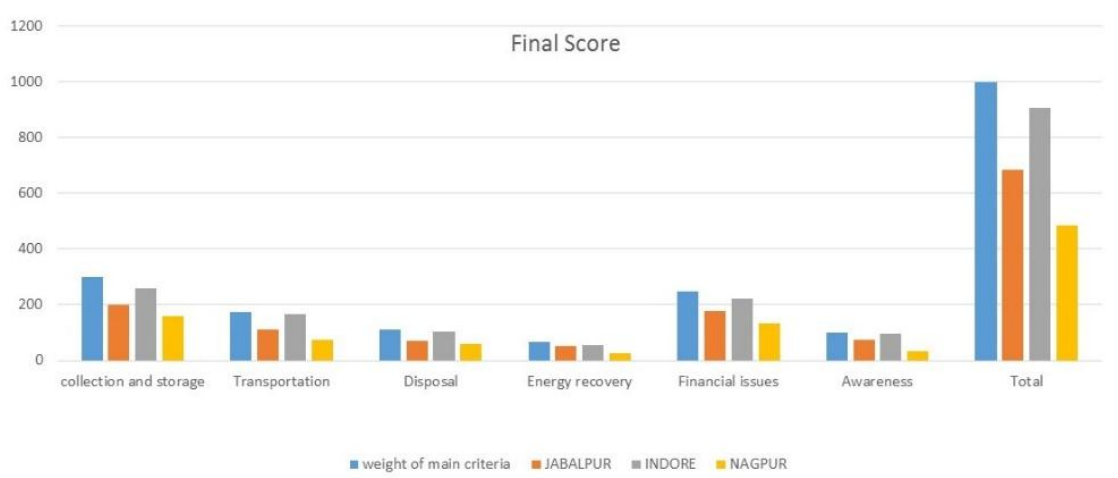

Figure 2:-Performance of Jabalpur, Indore and Nagpur

\section{Conclusion:-}

Municipal solid waste management is an important factor concerning wellness of the natural environment. In the current study, by pairwise comparison of every element in the hierarchy model, judgemental values were calculated that were further used for the calculation of weightage of the criteria and sub criteria of SWM indicators. The whole process of calculation was termed as analytical hierarchy process (AHP). Referring the table, it can be stated that Indore is efficient in all the categories in SWM. Indore has the best waste transportation system with the usage of multiple number of vehicles (95.33\%), highest percentage of social awareness created by implementing social media, mobile application, visual and audible social media as well as advertisements. Jabalpur has performed moderately in all the categories while Nagpur has to the lowest percentage in all the categories.

Though every city corporation have some proposed plans viz. waste to energy recovery plant proposal in Nagpur as well as Indore city etc. and they are taking positive steps for the contribution in the cleanliness of the nation, these cities should follow steps taken by well managed cities for quicker growth in the field of solid waste management. 


\section{References:-}

1. David C Wilson1,Comparative analysis of solid waste management in 20 citiesWaste Management \&Research 30(3) 237-254 () The Author(s) 2012.

2. Astrid Allesch Assessment methods for solid wastemanagement: A literature review Waste Management \& Research2014, Vol. 32(6) 461-473.

3. Joan Col_on, Determination of the energy and environmental burdens associated with the biological treatment of source-separated Municipal Solid Wastes This journal is The Royal Society of Chemistry 2011.

4. Mizpah Asase, Comparison of municipal solid waste management systems in Canada and Ghana:A case study of the cities of London, Ontario, and Kumasi, Ghana Waste Management 29 (2009) 2779-2786 Elsevier.

5. Reed, R. and P.T. Recommened Methods for the Disposal of Sanitary waste from Temporary Field Medical Facilities Disasters Vol 18, No 4.

6. Dr. Raveesh Agarwal, WASTE MANAGEMENT INITIATIVES IN INDIA FOR HUMAN WELL BEING, European Scientific Journal June 2015 /SPECIAL/ edition ISSN: 1857 - 7881 (Print) e - ISSN 1857- 7431.

7. List of cleanest cities in India - Wikipedia.

8. Debeshi Gooptu, Making India's cities smarter,2017-0612 (http://www.addthis.com/bookmark.php?v=250\&username=questex).

9. Smart City Mission Statement And Guidelines, Ministry Of Urban Development, Government Of India.

10. Harshul Parekh et. al. Identification and assigning weight of indicator influencing performance of municipal solid waste management using AHP, KSCE Journal of Civil Engineering (2015) 19(1):36-45.

11. M. Yavuz, Equipment selection based on the AHP and Yager's method,J. S. Afr. Inst. Min. Metall. vol.115 n.5 Johannesburg May. 2015.

12. Atiq Uz Zaman et. al. The zero waste index: a performance measurement tool for waste management systems in a 'zero waste, , Elsevier Journal of Cleaner Production 50 (2013) 123-132.

13. Saaty T. Analytic hierarchy process, planning, piority setting, resource allocation, McGraw- Hill, New york. 1980.

14. Satty, T. Multicriteria decision making: The analytic hierarchy process, RWS Pittsburgh Publication, Pittsburgh 1980.

15. Central Pollution Control Board of India (CPCB), "Status of solid waste management in metro cities", CPCB. 1998. 